\title{
Ultrafiolett stråling og sykdomsrisiko
}

\author{
Trude Eid Robsahm ${ }^{1}$ og Steinar Tretli ${ }^{1,2}$ \\ 1) Kreftregisteret, Institute of Population-Based Cancer Research, Montebello, 0310 Oslo \\ 2) Institutt for samfunnsmedisin, NTNU, Trondheim \\ Korrespondanse: TE Robsahm, Kreftregisteret, Montebello, 0310 Oslo \\ Telefon: 23333967 Telefax: $22451370 \quad$ E-post: trude.eid.robsahm@kreftregisteret.no
}

\section{ENGLISH SUMMARY}

Robsahm TE, Tretli S. Ultraviolet radiation and health. Nor J Epidemiol 2004; 14 (2): 187-191.

\begin{abstract}
The major source of human exposure to ultraviolet (UV) radiation is sunlight, and UV-exposure influences the human health in two ways. Firstly, the ultraviolet components of sunlight are established as the main cause of all skin cancers. Based on this knowledge, encouragement of sun-protective behaviour seems to be the most effective public health measure to reduce incidence of skin cancer in the white population. Secondly, solar radiation is our main source of vitamin D, which is synthesised in the skin as a response to UV exposure. The hormone form of vitamin D is involved in several biological mechanisms. During the last few years, an increasing number of studies indicate that vitamin D inhibit the progression of several cancer forms and, thus, may increase the survival rate. A high level of vitamin D is also associated with a reduced risk of bone and skin diseases, multiple sclerosis, diabetes, and cardiovascular diseases. The two potential effects of UV-exposure are not necessarily contradictory if the UV-exposure is moderate.
\end{abstract}

\section{INNLEDNING}

Solen er ansvarlig for alt liv på jorden. Men, de ultrafiolette (UV) komponentene som utgjør ca. 5\% av strålene som når jordens overflate, er assosiert med skadelige effekter. Stråleintensiteten varierer med breddegrader, årstid, tid på dagen, skydekke og ozonlag. Kultur, bekledning og solens posisjon i forhold til kroppen påvirker graden av UV-eksponering på huden. Eksponering for UV-stråling fra sollys er en etablert risikofaktor for alle typer hudkreft. Med bakgrunn i etiologisk kunnskap ønsker man å innarbeide solingsvaner i befolkningen slik at risikoen for hudkreft reduseres. I denne sammenhengen må også UV-eksponeringens betydning for produksjon av vitamin $\mathrm{D} i$ huden taes med. Vitamin D er et hormon, som inngår i en rekke biologiske mekanismer. Et økende antall studier indikerer at et høyt nivå av vitamin $\mathrm{D}$ kan redusere risikoen for både å få og dø av flere kreftformer, samt risikoen for å få flere kroniske sykdommer. Både når det gjelder risiko for føflekkreft og produksjon og vitamin D i huden er det de korte bølgelengdene, 280-315 nanometer (UVB), som er mest i fokus $(1,2)$. Likevel, disse to mulige effektene av UV-stråling behøver ikke å være i konflikt med hverandre.

\section{UV OG HUDKREFT}

Det finnes tre hovedtyper hudkreft; basalcellekarsinom, plateepitelkarsinom og føflekkreft (malignt melanom). Resultater fra en lang rekke epidemiologiske studier, fra hele verden, gir en sterk indikasjon på at UV-eksponering er den viktigste etiologiske årsaken til de tre formene for hudkreft. I den hvite befolkningen øker forekomst av hudkreft lineært med avtagende av- stand til ekvator. I Norge er forekomsten av basalcellekarsinom og plateepitelkarsinom firedoblet siden midt på 1950-tallet. Vi ser en klar geografisk variasjon i forekomsten som samsvarer med forskjeller i UVstråling og i klima. I 2002 var den aldersjusterte insidensraten for plateepitelkarsinom 35 per 100000 personer i Aust-Agder mens raten i Finnmark var 8.

Plateepitelkarsinom oppstår hyppigst i hode- og nakkeregionen og på håndbaken (3-5). Blant menn oppstår mer enn $20 \%$ av tilfellene på ytre øre mot bare $1-3 \%$ blant kvinner $(4,6)$, som sannsynligvis skyldes forskjeller i hårlengde og eksponering av ørene. Slike observasjoner støtter antakelsen om at akkumulert eksponering gjennom hele livet øker risikoen for denne typen hudkreft.

Ondartet føflekkreft er den mest alvorlige formen for hudkreft. I Norge ser vi en seksdobling i forekomst av denne kreftformen perioden 1957-2001, fra 2,6 til ca. 15 per 100000 personer. Mortaliteten har også økt $\mathrm{i}$ denne perioden, noe som underbygger at økningen $\mathrm{i}$ insidensen ikke bare er et utrykk for økende diagnoseintensitet. Ser man på forekomsten i forhold til innbyggertall, ligger Norge på tredje plass i verden med ca. 1000 nye tilfeller hvert år. Foran oss på statistikken er Australia og New Zealand som ligger mye nærmere ekvator (20-45 $\left.{ }^{\circ} \mathrm{S}\right)$ og som derfor har et annet klima enn oss. Føflekkreft er assosiert med gjentatte episoder med sterk UV-stråling (7-9), som sammenfaller med vår solingsadferd $i$ et klima med korte somre og kalde vintre. Figur 1 viser den årlige variasjonen i UVstålingen for hele landet (10). Etter en vinter uten UVeksponering, ivrer vi hver vår etter solstrålene og med vinterblek ubeskyttet hud utsetter vi oss for intens soling. 

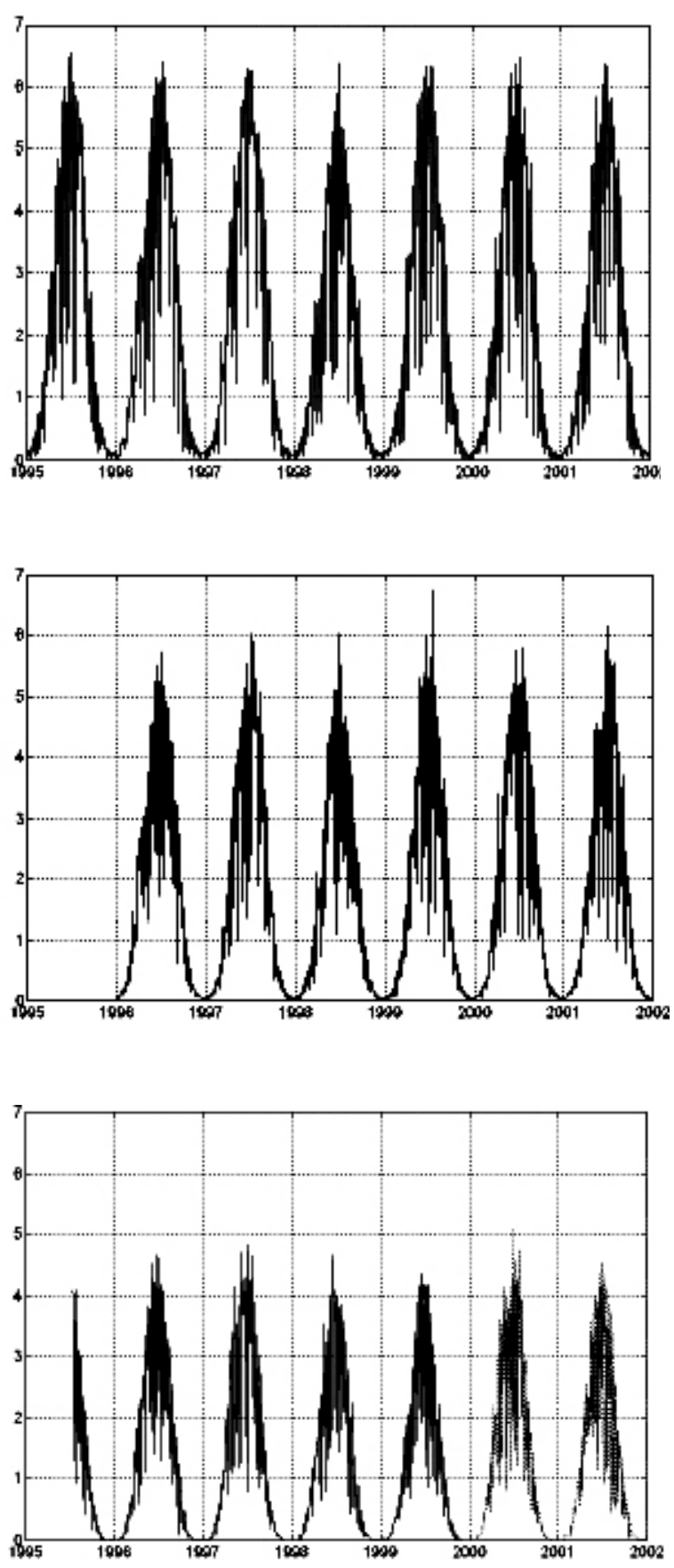

Figur 1. Årlig mønster for daglig UV-eksponering i Sør-Norge (øverst), Midt-Norge (midten) og Nord-Norge (nederst) i perioden 1995-2002 (10).

Man ser en klar nord-sør gradient i forekomst av føflekkreft i Norge. Risikoen for føflekkreft er mer enn dobbelt så stor for de som bor i Sør- og Øst-Norge sammenlignet med de som bor nord i landet, og den høyeste risikoen ser man i sørøstlige kystområder (Figur 2). Ikke bare er UV-nivået i sollyset lavere $\mathrm{i}$ nord men det er også sannsynlig at man har en annen solingsadferd på grunn av lavere temperaturer. Man kan tenke seg at befolkningen i Nord-Norge i større grad beholder klærne på og oppnår en fysisk beskyttelse mot skadelige UV-stråler.
Kvinner og menn har ulike klesvaner i sola og blottlegger ulike deler av kroppen. I samsvar med våre sommerlige klesvaner, finner vi hos kvinner de fleste lesjonene på mage, lår og legger. Hos mennene oppstår over halvparten av lesjonene på mage, bryst og skuldre. I Norge observerte man tidlig på nittitallet en økt forekomst av føflekkreft på kvinnebryst, som har vært en sjelden forekommende lokalisasjon. Dette ble sett $\mathrm{i}$ sammenheng med toppløs soling blant kvinner tidlig på åttitallet (3).

Sterk soleksponering og solbrenthet i barneårene har lenge vært antatt som en vesentlig faktor i forhold til risiko for føflekkreft senere i livet. Dette har satt fokus på viktigheten av å beskytte barn med solfaktor og klær. Men nyere studier viser at soleksponering påvirker risiko for føflekkreft uavhengig av når i livet eksponeringen skjer (9). I en norsk undersøkelse har man sett på hvor folk var født, oppvokst og bodde senere i livet $\mathrm{i}$ forhold til risiko for føflekkreft (11). Resultatene viser en reduksjon i risiko for de som vokste opp i Sør-Norge og senere flyttet til NordNorge, sammenlignet med de som ble boende i sør hele livet. Det samme gjaldt de som flyttet fra nord til sør; kreftrisikoen økte i forhold til de som vokste opp og ble boende i Nord-Norge.

Solkrem med beskyttelsesfaktor forebygger solbrenthet, men samtidig forlenger man den tiden man tilbringer i solen. Det er et paradoks at flere studier viser en høyere risiko for føflekkreft blant de som bruker solkrem med beskyttelsesfaktor enn de som ikke bruker solkrem $(12,13)$. Et annet aspekt med solkremer er at man ikke kjenner effekten av de kjemiske komponentene ved lang tids bruk.

\section{UV OG VITAMIN D}

UV initierer syntese av vitamin D i huden $\left(\mathrm{D}_{3}\right)$ hvor 7dehydrokolesterol i epidermis konverteres av UVBstråler med bølgelengde 300-315 nanometer. Dette er omtrent det samme spekter som gir erythem (rød hud). Produksjon av vitamin D i huden reduseres dermed av alle tradisjonelle solkremer med beskyttelsesfaktor. UV-stråling spiller en vesentlig rolle for vårt vitamin D-nivå, også her i Norge $(14,15)$. Nivået av vitamin D i befolkningen er lavt i vintermånedene, når solen står lavt over horisonten og UV-strålene ikke treffer jordoverflaten. Som respons på økende UV-innhold utover våren stiger nivået av vitamin $\mathrm{D}$ og er ca. 50\% høyere om sommeren sammenlignet med vinteren. Det maksimale UV-nivået er høyest i sør (Figur 1) mens inntak av D vitamin-rike matvarer er høyere i nord. Nivået av- og variasjonen i vitamin $\mathrm{D}$ gjennom året er derfor sannsynligvis lik for hele landet.

Den aktive formen av vitamin $\mathrm{D}$, kalsitriol, får man etter to hydroxyleringer, først i leveren og deretter $i$ nyrene (15). Men man har også observert at kalsitriol dannes i bryst-, prostata- og i tykktarmsvev (16). Kalsitriol er mest kjent som et kalsium-regulerende hormon men det inngår $\mathrm{i}$ en rekke andre biologiske mekanismer (14). 


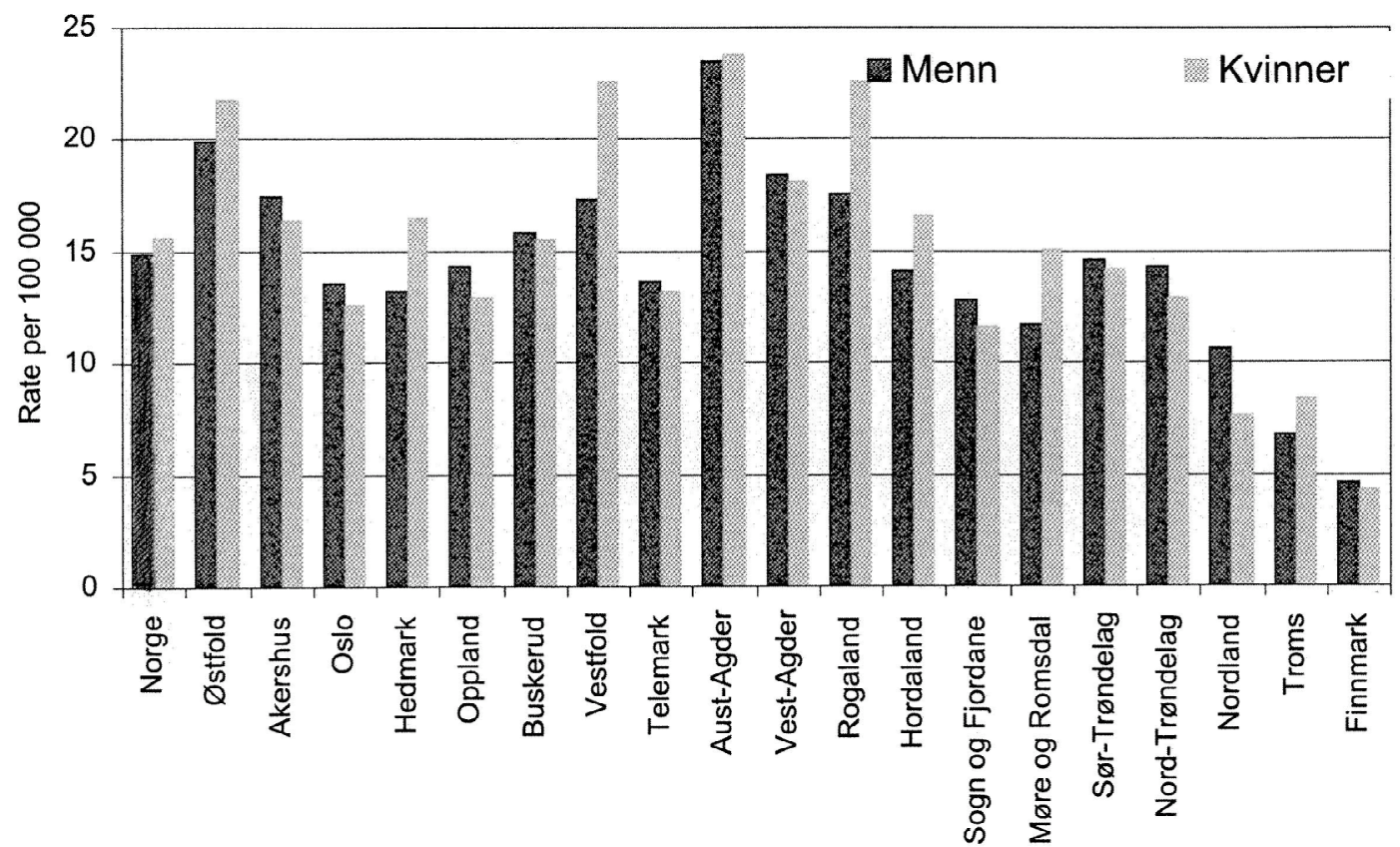

Figur 2. Antall nye tilfeller av føflekkreft, per 100000 personer, etter fylker i perioden 1997-2001 (www.kreftregisteret.no).

Evnen til å produsere $\mathrm{D}_{3} \mathrm{i}$ huden avtar med økende alder $(17,18)$. Eldre mennesker har også ofte et lavt inntak av vitamin D fra kosten, hvor fet fisk, egg, vitaminisert margarin og tran er de viktigste næringsmidlene. Mennesker med mørk hud trenger en større UVdose for å oppnå et adekvat vitamin D-nivå (19) og på grunn av kultur og religion er enkelte folkegruppene ofte fysisk beskyttet mot UV-stråling gjennom klær.

\section{Vitamin D og kreft}

Sammenhengen mellom vitamin D og kreft ble første gang beskrevet av Suda og kollegaer i 1981. De demonstrerte hvordan kalsitriol hemmer celledeling og øker differensieringen av kreftceller. Flere eksperimentelle studier viser at kalsitriol også fremmer celledød og hemmer tumorvekst (16,20-23). Epidemiologiske studier viser at forekomsten og dødeligheten av kreft i bryst, prostata og tykktarm er større i nord sammenlignet med i sør, og man tror at forskjeller i UVeksponering og i vitamin D-nivå kan forklare disse resultatene (24-28). Resultater fra en ny norsk studie viser at pasienter som fikk diagnosen bryst-, prostataeller tykktarmkreft tidlig på høsten, den årstiden hvor vitamin D-nivået i befolkningen er høyest, hadde 25\% høyere overlevelsesrate enn de pasientene som fikk kreftdiagnosen i løpet av vinteren (29). Både de eksperimentelle og epidemiologiske studiene indikerer at vitamin D kan hemme progresjon av visse kreftformer og at et høyt vitamin D-nivå kan bedre prognosen ved en kreftsykdom. Det er også studier som indikerer at vitamin D samvirker med og øker effekten av strålebehandling og dermed øker overlevelsen ved kreftsykdom $(21,30)$.

\section{Vitamin D og andre sykdommer}

Vitamin D er nødvendig for en normal mineralisering av skjelettet. Det er velkjent at mangel på vitamin D kan gi rakitt (engelsk syke) hos barn og osteomalaci hos voksne. Allerede i 1919 oppdaget man at rakitt kunne behandles med tran (31) og UV-eksponering (32). Etter hvert er også en lang rekke andre kroniske sykdommer assosiert med mangel på vitamin D eller UV-stråling, selv om man ikke tror at vitamin D er en unik risikofaktor for disse sykdommene. Det ser ut til at varigheten og omfanget av vitamin D-mangel er viktig og at dette kan samvirke med andre kjente risikofaktorer for sykdom som ernæring, virus og arv (33). Det diskuteres også hvorvidt vitamin D kan gis for å forebyggende osteoporose (34). Sammenhengen mellom vitamin D-mangel og psoriasis er velkjent (35), hvor UV-eksponering er en etablert behandlingsform. I de senere årene har det vært økende fokus på sammenhengen mellom vitamin D og multippel sklerose (MS) (36-38) hvor man ser at forekomsten av MS er større i solfattige områder. Både risikoen for MS (39) og schizofreni (40) er funnet å være omvendt assosiert med mors vitamin D-nivå i fosterlivet. En tilsvarende sammenheng har man observert for diabetes I (41-42), som forsterker antakelsen om at mors vitamin D-nivå under svangerskapet kan spille en vesentlig rolle for barnets sykdomsrisiko senere i livet. Også diabetes II, høyt blodtrykk og kardiovaskulære sykdommer er assosiert med lave nivå av eller mangel på vitamin $\mathrm{D}$ (43). Lavt vitamin D-nivå induserer insulinresistens og reduserer insulinsekresjon og kan på denne måten være knyttet til disse sykdommene (43). 


\section{OPPSUMMERING}

Den store økningen i hudkreft-forekomst i den hvite befolkningen de siste 30 år har resultert i omfattende forskning på årsaksammenhenger. På bakgrunn av denne forskningen har man i mange land utarbeidet retningslinjer for sunne solingsvaner, som Kreftforeningens "solvettregler" (www.kreftforeningen.no). Arbeidet med å etablere solrestriktive holdninger, som er det viktigste virkemiddelet for å forebygge hudkreft, kan forstyrres av et økende fokus på gunstige effekter av vitamin $\mathrm{D}$ i forhold til andre sykdommer. Ti minutter med soleksponering av ansikt og hender er antatt å være tilstrekkelig for å oppnå et adekvat vitamin Dnivå i forhold til kalsiumbalansen hos friske voksne mennesker i alderen 20-60 år. Ved sterk og langvarig soleksponering vil det dannes inaktive vitamin Dmetabolitter (1). Selv om man i løpet av sommeren opparbeider et høyt vitamin D-nivå vil dette synke i løpet av vinteren. Både i forhold til de potensielt krefthemmende effektene av vitamin D og dets forebyggende effekt $\mathrm{i}$ forhold til flere kroniske lidelser skulle nivået av vitamin D vært stabilt høyt (44). UV-stråling fra solarier initierer produksjon av vitamin $\mathrm{D}$, men solarie-sol kan også gi solforbrenning og bidrar til å øke den akkumulerte UV-dosen. For å opprettholde et høyt vitamin D-nivå gjennom vinteren kunne man supplere med inntak av vitamin D fra tilskudd dersom man ikke har et vitamin D-rikt kosthold.

\section{REFERANSER}

1. Lal H. Vitamin D: Non-skeletal actions and effects on growth. Nutr Res 1999; 19: 1683-1718.

2. de Gruijl FR. Photocarcinogenesis: UVA vs UVB radiation. Skin Pharmacol Appl Skin Physiol 2002; 15: 316-20.

3. Magnus K. The Nordic profile of skin cancer incidence. A comparative epidemiological study of three main types of skin cancer. Int J Cancer 1991; 47: 12-19.

4. Iversen T, Tretli S. Trends for invasive squamous cell neoplasia of the skin in Norway. Br J Cancer 1999; 81: $528-31$.

5. MacKie RM. Skin Cancer (2. Edn). Martin Dunitz Ltd, London, 1996.

6. Kaldor J, Shugg D, Young B, Dwyer T, Wang YG. Non-melanoma skin cancer: ten years of cancer registrybased surveillance. Int J Cancer 1993; 53: 886-91.

7. Magnus K. Habits of sun exposure and risk of malignant melanoma: an analysis of incidence rates in Norway 1955-1977 by cohort, sex, age and primary tumor site. Cancer 1981; 48: 2329-35.

8. Parkin DM, Khlat M. Studies of cancer in migrants: rationale and methodology. Eur J Cancer 1996; 32A: $761-71$.

9. Tucker MA, Goldstein AM. Melanoma etiology: where are we? Oncogene 2003; 22: 3042-52.

10. Johnsen B, Mikkelborg O, Hannevik M, et al. The Norwegian UV-monitoring program, period 1995/96 to 2001. Statens Strålevern, Østerås, 2002.

11. Robsahm TE, Tretli S. Cutaneous malignant melanoma in Norway: variation by region of residence before and after the age of 17. Cancer Causes Control 2001; 12: 569-76.

12. Australian Institute of Health and Welfare. Cancer in Australia 1995 (AIHW). Incidence and Mortality Data for 1995 and Selected Data for 1996. AIHW, Canberra, 1998.

13. Diffey BL. Human exposure to ultraviolet radiation. In: Hawk JLM (ed). Photodermatology, Chapman and Hall, London, 1998: 5-24.

14. Vik T, Try K, Stromme H. The vitamin D status of man at 70 degrees north. Scand J Clin Lab Invest 1980; 40: $227-32$.

15. Holick MF. Vitamin D: Photobiology, Metabolism, and Clinical Application. In: The Liver: Biology and Pathobiology (3. Edn) Arias IM, Boyer JL, Fausto N, Jakoby WB, Schachter DA, Shafritz DA (Eds). Raven Press, NY, 1994.

16. Cross HS, Bajna E, Bises G, et al. Vitamin D receptor and cytokeratin expression may be progression indicators in human colon cancer. Anticancer Res 1996; 16: 2333-8.

17. Eberling PR, Sandgren ME, DiMagno EP, et al. Evidence of an age-related decrease in intestinal responsiveness to vitamin D: relationship between serum 1,25 Dihydroxyvitamin D3 and intestinal Vitamin D receptor concentrations in normal women. J Clin Endocrinol Metab 1992; 75: 176-82.

18. McKenna KJ. Differences in Vitamin D status between countries in young adults and the elderly. Am J Med 1992; 93: 69-77.

19. Matsouka LY, Wortsmann J, Haddad JG, et al. Pigmentation and the cutaneous synthesis of vitamin D. Arch Dermatol 1991; 127: 536-8. 
20. Stumpf WE, Sar M, Reid FA, et al. Target cells for 1,25-dihydroxyvitamin D3 in intestinal tract, stomach, kidney, skin, pituitary, and parathyroid. Science 1979; 206: 1188-90.

21. Buras R, Schumaker LM, Davoodi F, et al. Vitamin D receptors in breast cancer cells. Breast Cancer Res Treat 1994; 31: 191-202.

22. Danielsson C. Molecular Mechanism of Cell Regulatory Properties of Vitamin D Analogues in Human cancer Cell Lines. Avta Univercitas Upsaliensis, Sweden, 1998.

23. Metha RG, Metha RR. Vitamin D and cancer. J Nutr Biochem 2002; 13: 252-64.

24. Garland FC, Garland CF, Gorham ED, Young JF. Geographic variation in breast cancer mortality in the United States: a hypothesis involving exposure to solar radiation. Prev Med 1990; 19: 614-22.

25. Schwartz GG, Wang MH, Zhang M, Singh RK, Siegal GP. 1】25-Dihydroxyvitamin D (Calcitriol) inhibits the invasiveness of human prostate cancer cell. Cancer Epidemiol Biomark Prev 1997; 6: 727-32.

26. John EM, Schwarts GG, Dreon DM, Koo J. Vitamin D and breast cancer risk: The NHANES I Epidemiological follow-up study, 1971-1975 to 1992. Cancer Epidemiol Biomark Prev 1999; 8: 399-406.

27. Freedman DM, Dosemeci M, McGlynn K. Sunlight and mortality from breast, ovarian, colon, prostate, and non-melanoma skin cancer: a composite death certificate based case-control study. Occup Environ Med 2002; 59: $257-62$.

28. Grant WB. An estimate of premature cancer mortality in the US due to inadequate doses of solar ultraviolet-B radiation. Cancer 2002; 94: 1867-75.

29. Robsahm TE, Tretli S, Dahlback A, Moan J. Vitamin D3 from sunlight may improve the prognosis of breast-, colon- and prostate cancer (Norway). Cancer Causes Control 2004; 15: 149-58.

30. Sundaram S, Sea A, Feldman S, et al. The combination of a potent vitamin D3 analog, EB 1089, with ionizing radiation reduces tumor growth and induces apoptosis of MCF-7 breast tumor xenografts in nude mice. Clin Cancer Res 2003; 9: 2350-6.

31. Mellanby E. The present state of knowledge concerning accessory food factors. Med Res Spec Rep Ser SRS38, 1919.

32. Huldschinsky K. Heilung von Rachjitis durch kuenstliche Hohensoone. Dutsch Med Wochenschr 1919; 45: 712.

33. Gilli O. Sunlight Robbery, health benefits of sunlight are denied by current public health policy in the UK. Health Research Forum Occational Reports No 1, 2004.

34. Ljunghall S, Charles P, Falch J, et al. Vitamin D och osteoporos. Nord Med 1995; 110: 253-7.

35. Kira M, Kobayachi T, Yoshikawa K. Vitamin D and the skin. J Dermatol 2003; 30: 429-37.

36. Hayes CE, Cantorna MT, DeLuca HF. Vitamin D and multiple sclerosis. Proc Soc Exp Biol Med 1997; 216: 21-7.

37. van der Mei IA, Ponsonby AL, Blizzard L, Dwyer T.. Regional variation in multiple sclerosis prevalence in Australia and its association with ambient ultra-violet radiation. Neuroepidemiology 2001; 20: 168-74.

38. Munger K, Zhang SM, O'Reilly E, et al. Vitamin D intake and incidence of multiple sclerosis. Neurology 2004; 62: 60-5.

39. van der Mei IA, Ponsonby AL, Dwyer T et al. Past exposure to sun, skin phenotype, and risk of multiple sclerosis: a case-control study. BMJ 2003; 327: 316.

40. Davies G, Welham J, Chant D, et al. A systematic review and meta-analysis of Northern Hemisphere season of birth studies in schizophrenia. Schizophr Bull 2003; 29: 587-93.

41. Rothwell P, Gutnikov SA, McKinney PA, et al. Seasonality of birth in children with diabetes in Europe: multicentre cohortstudy. BMJ 1999; 319: 887-8.

42. McKinney PA. Seasonality of birth in patients with childhood Type 1 diabetes in 19 European regions. Diabetologica 2001; 44 [Suppl 3]: B67-74.

43. Boucher BJ. Inadequate vitamin D status: does it contribute to disorders comprising syndrome $\mathrm{x}$ ? Brit J Nutr 1998; 79: 315-27.

44. Vieth R. Why the optimal requirement for Vitamin D3 is probably much higher than what is officially recommended for adults. J Steroid Biochem Mol Biol 2004; 89-90: 575-9. 